\title{
Inhibitory Effect of Bombay Onion (Allium cepa L.) Extracts on Mitotic Chromosomes
}

\author{
Edy Suwarso $^{1 *}$, Dewi Nur Anggraeni \\ ${ }^{1}$ Faculty of Pharmacy, Universitas Sumatera Utara, Medan, Indonesia \\ ${ }^{2}$ Faculty of Biology, Universitas Medan Area, Medan, Indonesia
}

\begin{abstract}
Cancer is one of the world health problems. Free radical could damage cells and lead to cancer. Antioxidant compound could be found in some vegetable such as phenols and flavonoids. Flavonoids and phenol significantly decrease micronucleus formation on mitotic chromosomes. This present study aim to explore the inhibitory effect of Bombay onion extracts (BOE) on mitotic chromosomes induced by cyclophosphamide. Twenty-five mice (body weight 20-35 g) were divided into 5 groups, with 5 mice in each group. Normal control group (NCG) were given CMC $5 \mathrm{mg} / \mathrm{mice} / 7$ days. Mutagen control group (MCG) that is previously given as NCG, 4 hours later were given cyclophosphamide at a dose of $50.0 \mathrm{mg} / \mathrm{kg}$ bw intraperitoneally. Three treatment groups, group I (TG-I), TG-2, and TG-3, were given BOE with doses of 100; 200; and $400 \mathrm{mg} / \mathrm{kg}$ bw for 7 days, respectively. After 7 days, all three groups were treated similarly with MCG. Thirty hours later, all groups were put to death and femur bone marrows were analyzed to count the number of micronucleus. The results showed that the number of micronucleus in every 200 polychromatic erythrocyte cells at mitotic chromosomes for NCG is $29.8 \pm 2.387$, MCG with a value of I20.8 \pm 5.718 , TG-I showed $94.8 \pm 7.049$, TG-2 is $68.8 \pm 3.42$ I, and TG-3 which is $30.8 \pm 0.837$. TG-3 showed a similar result with NCG ( $p>0.05)$.
\end{abstract}

Keywords : mitotic chromosomes, Bombay Onion Extracts, femur bone marrow, micronucleus

\section{INTRODUCTION}

Antioxidants are substances or natural compounds that can protect cells from damage and aging due to reactive molecules and free radicals. Free radicals could disrupt the immune system, triggered degenerative diseases such as cancer, diabetes mellitus, coronary heart disease and immunodeficiency disorder. Antioxidants could neutralize free radicals leading to reduce cells damage. Antioxidant could scavenge free radical, and reduced damage to body systems (Lingga, 2012).

World Health Organization (WHO) reported that there have been more than 10 million cases of cancer per year in the world (Surh, 2003). Cancer is a disease characterized by uncontrolled cell division due to DNA damage leading to abnormal cell division. Mitotic chromosomes were indicated by the formation of micronuclei. However, carcinogens could trigger cells mitosis (Sutanto, 2009).
Micronucleus test, developed by Heddle (1973) and Schmid (1975), widely used to detect genotoxic effects (Saleh and Ahmad, 2010). Flavonoid and polyphenol are the examples of compounds with antimutagenic activity (Ishaq, et al., 2003). Bombay onion extract (BOE) contained several secondary metabolites, such as flavonoids with $\mathrm{IC}_{50}$ value as antioxidant was $88.087 \pm 0.333$ Sofa (2004).

\section{MATERIALS AND METHODS}

\section{Material}

Animals used in this study were male mice (Mus musculus) 25-35 g and obtained from the Laboratory of Pharmacology, Faculty of Pharmacy, Universitas Sumatera Utara (USU). Mice were maintained for approximately two weeks to adapted to environmental and food.

*Corresponding author email: parikesit5252@yahoo.co.id 


\section{Method}

This study was conducted by randomized design with a linear model. Twenty-five mice (20-35 g) were divided into 5 groups, with 5 mice in each group. Normal control group (NCG) were given CMC $5 \mathrm{mg} / \mathrm{mice} / 7$ days. Mutagen control group (MCG) were given cyclophosphamide at a dose of $50.0 \mathrm{mg} / \mathrm{kg}$ intraperitoneally, 4 hours after NCG administration.

Three treatment groups, which are group TG-1, TG-2, and TG-3, were given BOE at the doses of 100; 200; and $400 \mathrm{mg} / \mathrm{kg}$ respectively for 7 days. Hereafter, three groups were treated similarly with MCG. After treatment, animals were sacrificed and femur bone marrows were analyzed to count the number of micronucleus.

\section{RESULTS AND DISCUSSIONS}

Cyclophosphamide used in this study could increased micronucleus femur leading to mitotic chromosomes (Krishna and Hayashi, 2000). Cyclophosphamide was given at the dose of $50 \mathrm{mg} / \mathrm{kg} \mathrm{bw}$, intraperitoneally to induce genotoxicity/mutagenicity.

The observation of micronucleus smear using a microscope with 40x magnification could be observed in Fig. 1.

Micronucleus assay was performed using femur bone marrow. Mitotic chromosome occurrence induced by peritoneal injection of cyclophosphamide at dose of $50 \mathrm{mg} / \mathrm{kg}$ bw. Number of micronucleus counted per 200 polychromatic erythrocytes were shown in Table 1.

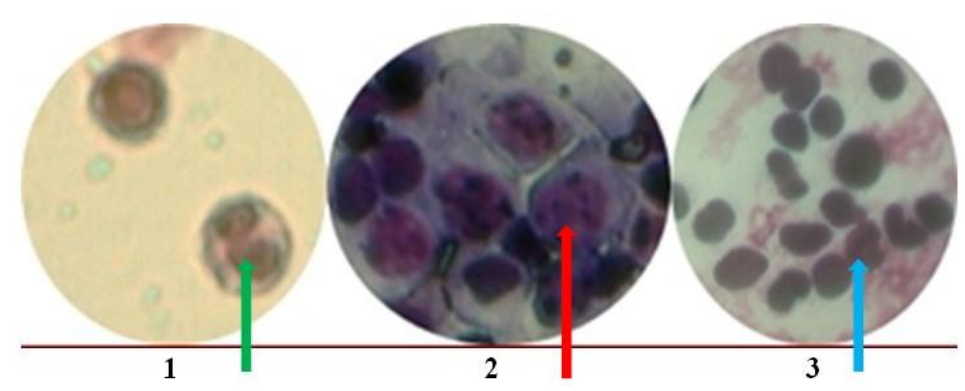

Figure I. Micronucleus observed Using Microscope with 40x magnification. (I) polychromatic erythrocyte cells without micronucleus, (2) polychromatic erythrocyte cells with micronucleus, (3) mature erythrocyte cells.

Table I. Number micronuclei in 200 polychromatic erythrocytes

\begin{tabular}{cccccc}
\hline \multirow{2}{*}{ Replication } & \multicolumn{2}{c}{ Control group } & \multicolumn{3}{c}{ Treatments group } \\
\cline { 2 - 6 } & $\begin{array}{c}\text { Negative } \\
\text { NCG }\end{array}$ & $\begin{array}{c}\text { Positive } \\
\text { MCG }\end{array}$ & TG-1 & TG-2 & TG-3 \\
& & & & & \\
\hline & 28 & 112 & 83 & 65 & 32 \\
1 & 33 & 122 & 94 & 70 & 31 \\
3 & 27 & 119 & 98 & 68 & 30 \\
4 & 30 & 124 & 98 & 67 & 31 \\
5 & 31 & 127 & 101 & 74 & 30 \\
& & & & & \\
\hline Mean & 29.8 & 120.8 & 94.8 & 68.8 & 30.8 \\
\pm & \pm & \pm & \pm & \pm & \pm \\
S.D. & 2.387 & 5.718 & 7.049 & 3.421 & 0.837 \\
& & & & & \\
\hline
\end{tabular}


Based on the result, BOE administration at a dose of $400 \mathrm{mg} / \mathrm{kg}$ bw reduced number of micronuclei $8 \pm 0.837$. however, this result showed no difference with the negative control $(p>0.05)$.

\section{CONCLUSION}

Bombay Onion extract (BOE) inhibit mitotic chromosomes at the a dose of 400 $\mathrm{mg} / \mathrm{kg}$ bw. However, number of micronuclei showed no difference with negative control $(p>$ $0.05)$.

\section{ACKNOWLEDGMENTS}

The authors thank to Dean of the Faculty of Pharmacy USU who has given us the opportunity to conduct independent research under the title "Inhibitory Effect of Bombay Onion (Allium cepa L.) Extracts on Mitotic Chromosomes".

\section{REFERENCES}

Blois, M.S., 1958, Antioxidant Determinations by Use of a Stable Free Redical, Nature, I 8 I (46I7), I I 98-I 200.

Heddle, J.A., 1973. A Rapid in vivo Test for Chromosomal Damage, Mutat. Res., 18(2), 187-190.
Ishaq, G.M., Shah, M.Y. and Tanki, S.A., 2003, Cancer Chemoprevention through Natural Antimutagenic Agents, JKPractioner, 2(10), I0I.

Krishna, G. and Hayashi, M., 2000, In vivo Rodent Micronucleus Assay: Protocol, Conduct and Data Interpretation, Mutat. Res., 455(I-2), I55-166.

Linggga, L., 2012, Mengenal Lebih Jauh Sumber Antioksidan Unggulan, Jakarta: Penerbit P.T. Elex Media Komputindo.

Saleh J. and Ahmad K., 2010, Clastogenic Studies on Tandaha Dam water in Asser, J. Black Sea Medit. Environ., I6(I), 33.

Schmid, W., 1975, The Micronukleus Test, Mutation Res., 3 I (I), 9-I5.

Sofa, H.M., 2014, Efek Antioksidan Ekstrak Bawang Bombay (Allium cepa L.) Dengan Metode DPPH (I,I-diphenyl-2picrylhydrazil) Secara Spektrofotometri Sinar Tampak, Essay, Universitas Muslim Nusantara, Medan.

Surh, Y.J., 2003, Cancer Chemoprevention with Dietary Phytochemicals, Nat. Rev. Cancer, 3(10), 768-780.

Sutanto, 2009, Awas 7 Penyakit Degeneratif, Yogyakarta: Paradigma Indonesia. 